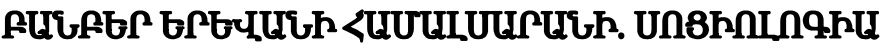 Journal of Sociology: Bulletin of Yerevan University
}

2021, № 2, 76-87

https://doi.org/10.46991/BYSU:F/2021.12.2.076

Sinkuuluuk unghngnqhu

\section{WORKING IN THE SPHERE OF FOOD TRADE AND SERVICE IN ARMENIA: PATTERNS OF PRECARIOUSNESS}

\section{SRBUHI MICHIKYAN}

The food trade and service sector is considered the most uncertain, with a strong expression of instability worldwide and in Armenia. Currently, the term precariousness is widely used to describe the uncertainty and risks in the field. Research on food trade and services in Armenia has been conducted recently, but there have been no sociological studies on patterns of precariousness. The study of patterns of precariousness provides an in-depth look at sectoral uncertainty and risk concerning broader social structures. The purpose of this article is to study the patterns of precariousness expressed in the field through secondary analysis, which will provide opportunities for deeper analysis in the future, emphasizing the expressions of social injustice and inequality.

Keywords: precariousness, precarious patterns, food trade, food service sector, social justice

Introduction: During the COVID-19 pandemic, many workers lost their jobs or had it postponed, but some sectors were affected with uncertainty and risk of future lockdown the most (airlines, leisure facilities, restaurants, oil \& gas drilling, auto parts, and equipment sectors are the top 5) (Haydon, Kumar, 2020). This problem once again showed the vulnerability of employees of several sectors to be in a riskier unstable and socially insecure condition than other working sectors. We have seen this situation also in Armenia, where especially food trade and services were mostly affected with an uncertain situation (Mkrtchyan et al., 2016, 46-48). Recent studies connected to the labor rights, justice, and favorable working conditions in Armenia show that the problems of informal employment in Armenia are crucial in the spheres of direct services, especially retail-wholesale, renovation $(38.7 \%)$, hotel/restaurant service $(38.5 \%)$ (Mikaelian, 2016, 29). These sectors are most vulnerable in terms of instability, low level of occupational safety, limited access to the social security system, and lack of protection of collective interests (Gardawski, 2020, 4).

Nowadays, in labor studies, the term precariousness is commonly used to describe this kind of uncertainty, instability, and risk that accrues because of the nature of work. The working models and areas containing precarious elements differ from country to country (Standing, 2010; Vosko, 2010; Vosko, et al., 2009); they range from office work to freelance work, from part-time to seasonal and full-time work, and more. According to international researches, the catering and hotel sector is one of the sectors with the highest level of precarity in Europe (in 10 out of 12 surveyed countries the sector is pre-employment) (McKay et al., 2012, 44). 
As we already mentioned, the previous researches pointed out the employment of retail-wholesale, renovation, and hotel/restaurant services as most vulnerable concerning labor rights and justice in Armenia. However, comprehensive studies in these fields that would help us understand their connection to precarity, were not implemented yet. The conceptual development of precarity in researches on labor practicies in Armenia is an attempt to understand inequality and social disadvantages embedded in the structuration of contemporary neoliberal globalization.

The goal of this article was to take a step toward implementing the patterns of precariousness in researches in Armenia. As there already was research on the sector of foodservice and trade conducted in the July-September period of 2020 (Vermishyan et al., 2021), which is one of the sectors exaggerated with elements of precariousness, it was decided to use the data from the research for secondary analysis. The secondary analysis aimed to reveal possible expressions of precariousness that would provide reasonable preconditions for future research on justice and inequality in Armenia.

Literature review: The concept of precariousness takes its roots in the 1970s when the new generation of economists put forward the concept of the neoliberal labor market, which should help the state's development by raising the levels of competition in the market. However, the increase of this competition would lead the labor market to go through all aspects of human life, thus becoming more flexible. This flexibility transformed the market and led to instability for workers and their families. The description and discussion of this phenomenon take place in G. Standing's book (Standing, 2011).

The precarious working is also considered as one of the nowadays classes following elite, salariat and class of professionals. The precarious working class is considered as the class of mostly "unlucky" people, who are not rewarded with trust and compensation services within working practices if we compare with the salariat (McGovern et al., 2008).

However, precariousness is also used to describe the conditions of work as a specific level of instability (Campbell, Price, 2016, 1-19). This level of instability involves the low wages, lack of protection mechanisms or low level of selfimplementation, lack of employment guarantee, low level of management of income, working hours, and working conditions by the employee (Vosko, 2009, 7). In his studies, Campbell delivered a modified version of this classification by making four major clusters of working conditions precariousness: (1) lack of regulatory protection; (2) low wages; (3) high level of job insecurity; (4) low level of control over wages; working hours and conditions (Campbell, Price, 2016, 7).

The indicators of precariousness vary, and during the researches, scientists replenished the list of the representatives. They collected and outlined instability, security issues, social and economic vulnerability (Rodgers, Rodgers, 1989; McKay et al., 2012, 98) as the main indications of precariousness. The theoreti- 
cal basis for this study is the following scheme with the analysis of precarious employment. The scheme is created using the theoretical basis of the precarious criteria used in different empirical researches (Standing, 2011; McKay et al., 2012; Rodgers, Rodgers, 1989; Jonsson, Nyberg, 2010).

1. The first indicator is employment precariousness, which includes the instability of employment responsibilities, contracts, dismissal, and work regulations.

2. The second indicator is the precariousness of perspectives, which implies the creation of alternatives as a result of work, restrictions on actions aimed at career growth, such as instability of position, qualification, maintenance of income growth, social security.

3. The third indicator is the precariousness of income, which implies instability in the amount of income, the mechanisms of obtaining the latter, the minimum wage.

4. The last indicator is the precariousness of working conditions, which implies the instability of the nature of work (life-threatening work), schedule, opportunities to change it, breaks, vacations, accident insurance, health insurance.

For this, we selected two aspects to address for precarious. First, we will research the legal, social, and economic background of the workers involved in the sector. After we will concentrate on the indicators of precariousness and research their instability according to (1) responsibilities, (2) regulations, (3) income, (4) schedule, (5) health care, (6) insurance, and (7) perspectives.

The international empirical and theoretical practice shows that the youth, students and interns, are the most who enter the working sectors with a high level of precariousness. This is described as these people still don't have enough specifications to enter professional working sectors and enter easily available ones (Standing, 2011, 76). However, from first sight, we can notice that the youth is the group of people who still have opportunities to gain the skills (as they are students, have more freedom and less financial responsibilities).

Besides this group, there are others involved in the sectors with a high level of precariousness because of a shortage of skills or other opportunities. These are the migrants, ethnic minorities, lower-class representatives, women workers, elders, disabled people (McKay et al., 2012, 48), and so on.

Research methods: For this study, we used an already existing qualitative database on foodservice and trade sector research and conducted secondary research of the results of the survey (Vermishyan et al., 2020) ${ }^{1}$ for secondary analysis.

Findings: We already mentioned that precariousness is about the instabil-

${ }^{1}$ The research "Working conditions of employees in the field of food service and trade in Armenia" was conducted in 2020, July-September. 382 employees holding non-managerial positions in public catering establishments and supermarkets of Armenia took part in the research. The sample was based on the public catering and supermarkets' list operating at the time the survey was taken from the "SPYUR" open information system. This included 1072 monitoring units, a random sample was performed with a 95\% confidence level. 
ity of work in terms of workload, schedule, security, health conditions, employment, perspectives, and income, however, the threshold where stability ends and instability starts differs from state to state. For this, we will discuss working conditions provided in the Labor Code of the Republic of Armenia.

Overtime workload: According to the RA Labor Code, overtime work is allowed in case of natural disasters, accidents, incomplete work due to unforeseen obstacles, if termination of work may lead to material damage and/or endanger someone's life, there is a written term in the contract that leads to overtime work. According to the Labor Code, the overtime work should not exceed 4 hours during two consecutive days and 180 hours during the year. However, the point has lost its force starting from 24.06.10 (Labor Code of the Republic of Armenia, 2004). Working hours: Maximum working hours, including overtime, may not exceed 12 hours per day (including breaks) and 48 hours per week. The duration of the usual working hour must not exceed 40 hours per week (Labor Code of the Republic of Armenia, 2004). Breaks: Employees must be provided with a break of not more than 2 hours and not less than half an hour to rest and eat not later than 4 hours after the start of work. Vacations: Extended vacations must last 25 working days in case of a five-day working week and 30 working days in case of a six-day working week. Terms and procedure of salary payment: The salary is calculated every month and is paid to the employee at least once a month on working days until the 15th of the following month. An employer can pay a monthly salary more than once. Accidents and occupational diseases: In causes of occupational diseases and accidents, an official investigation is conducted in the organization. Occupational diseases and accidents are subject that employers must mandatorily register (Labor Code of the Republic of Armenia, 2004).

These short citations from the Labor Code briefly address the regulations for main indicators that are highlighted in precarious working conditions. After this discussion, it is relevant to address social and economic preconditions of people involved in precarious work before discussing the main indicators of precariousness.

Social preconditions: Starting from the general frequencies, $62.8 \%$ of responders live in Yerevan and $37.2 \%$ in the region. In addition, $93.2 \%$ of the respondents live in urban areas, $6.8 \%$ live in rural areas. $58.4 \%$ of the survey participants are female and $41.6 \%$ of them are male. Along with this picture, $64.3 \%$ of the respondents belong to the $17-36$ age group, and the most common age within surveyed is $23(\mathrm{n}=382) .30 .1 \%$ of the survey participants work in supermarkets, $69.9 \%$ work in catering establishments, moreover, women predominate significantly in the supermarket staff, and the picture in public catering establishments is close to equal $(\mathrm{n}=382$, Chi-square test, $\mathrm{P}$. Value $=-$ 0.184 , P. Sig. $=0.000$, Cramer's V $=0.184$ ). 
The results of the research show that in $68.6 \%$ of the cases $(n=379)$ the maximum educational level of employees in the field is secondary or secondary professional, moreover, $89.1 \%(n=376)$ of the participants are not currently studying in any educational institution. It's notable that in the age groups of 17 21 and 22-26 people with secondary or secondary professional educational level are predominant (accordingly $85 \%$ and $64.6 \%$, chart 1 .), and only $59 \%$ of $17-21$ $\mathrm{y} / \mathrm{o}$ and $14.8 \%$ of $22-26 \mathrm{y} / \mathrm{o}$ were still involved in educational institutions during the survey period.

Chart 1

Educational level by age groups

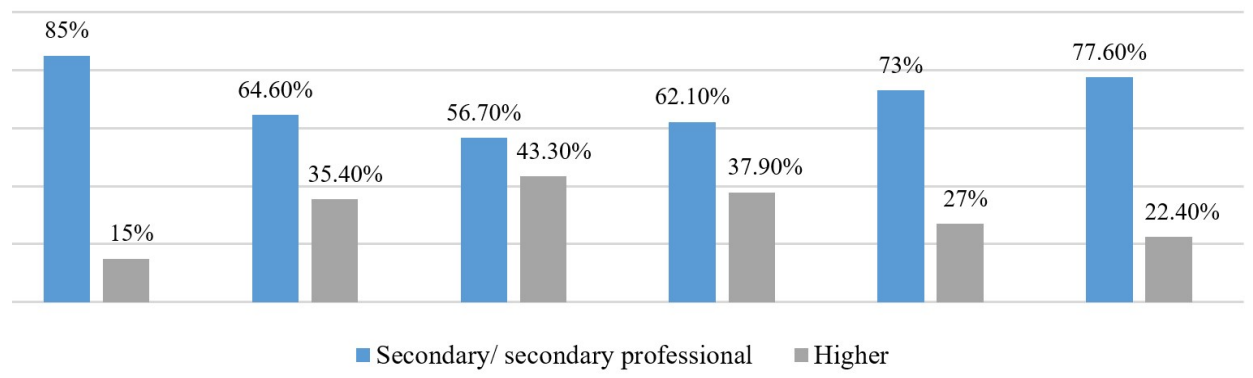

This indicates that the majority of those involved in the field, having a low level of education, are not obtaining an educational degree at present. In other words, young people working in the field, in particular, are people who have either not studied at universities or have not continued their professional education after receiving a bachelor's degree and are now engaged in nonprofessional work. The picture is similar among the participants of the qualitative research. Only 8 out of 18 narrative interviews have higher education (BA) or are currently studying at university. And the other 10 participants do not have higher education (only one of those is $19 \mathrm{y} / \mathrm{o}$, the rest are over $20 \mathrm{y} / \mathrm{o}$ ). It should be noted that differences in education by gender were not significant.

In terms of marital status, $47.2 \%$ of those employed in the sector are unmarried, $38.2 \%$ are married, and $14.5 \%$ are divorced or single. It is noteworthy, that among the respondents, the percentage of divorced or single people is predominant in food catering establishments, particularly in restaurants $(21.8 \%)$ and cafes $(18.8 \%, \mathrm{n}=379)$.

The results show that among the unmarried, the male representatives are predominant $(68.8 \%, n=115$ in supermarkets, $n=115,60.3 \%$ in catering establishments, $n=263$ ). In contrast, divorced women predominate, especially in public catering establishments $(19.6 \%, \mathrm{n}=263)$. Moreover, divorced women working in the field are predominant in regions, and non-married men are predominant in Yerevan (Chart 2). Moreover, 26-35 (32.4\%) and 36-45 (56.8\%) age groups are predominant within divorced. 


\section{Marital status by place of residence and gender}

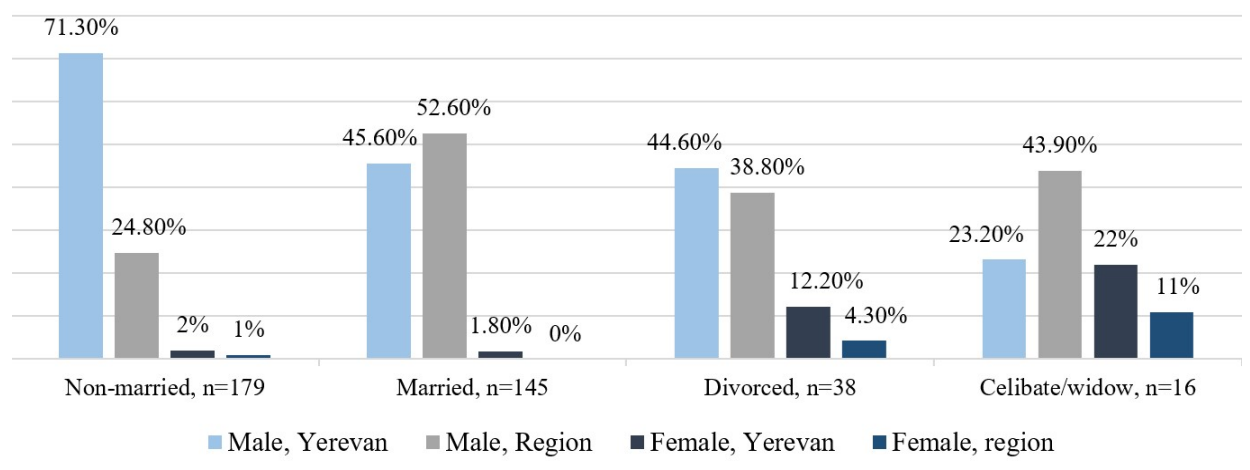

Research shows that the consequences of this field affect the employees' relationships with family members. The employees, whose work almost $(n=45$, $55.6 \%)$ or in general $(\mathrm{n}=15,73.3 \%)$ does not allow them to perform family responsibilities, work more than 10 hours a day at least within the half of the month (Chi-square test, P. Value $=0.342$, P. Sig. $=0.000$, Cramer's V = 0.342) Moreover, this effect is significantly seen in catering establishments $(n=381$, Chi-square test, P. Value $=0.231$, P. Sig. $=0.000$, Cramer's V =0.231).

Economic preconditions: Starting frequencies according to economic preconditions, we can see that the average monthly ("net") income from the workplace (including bonuses and other payments) in recent months is 135,000 AMD $(1 U S D=481 A M D)(n=235)$. However, 14\% of employees in the sector receive a salary lower than the minimum monthly wage defined by the legislation that is 68000 AMD $(\mathrm{n}=280)$.

It should be added that a statistically significant relationship was found between the gender of the respondents, the type of organization, and the amount of monthly income (P. Sign $=0.000$ for both): male employees are paid more (average 158,000 AMD) than females (average 120,000 AMD); employees of public catering establishments are paid higher (average 147,000 AMD) than employees of supermarkets (average 108,000 AMD).

About $2.4 \%$ of the survey participants $(n=378)$ did not have enough money even to buy food, $7.7 \%$ mentioned that the money was enough only for food, and according to $45.8 \%$, money was enough for only food and clothes. In general, the more opportunities in the welfare scale, the more the burden of dominance on the scale is directed to Yerevan (Chart 3).

During secondary analysis, we also paid attention to alternative financial support for employees. Even though there is no significant correlation between the fact who gets more financial support (residents of Yerevan or regions, employees of catering establishments, or supermarkets), it is significant that employees from regions more often get social benefits $(65 \%$, Chi-square test, $\mathrm{P}$. 
Value $=0.136$ P. Sig. $=0.009$, Cramer's V=0.136). The income of workers in the sector on average is $50.45 \%$ of their household income $(n=369$, std. Error= 1.477 , confidence interval $95 \%(47.54 \%-53.35 \%))$. If we separate the main expenses to which the income of employees is directed, the primary expenses are the repayment of loans and utilities, then the purchase of food, and clothes (Chart 4).

Chart 3

Financial situation by place of residence

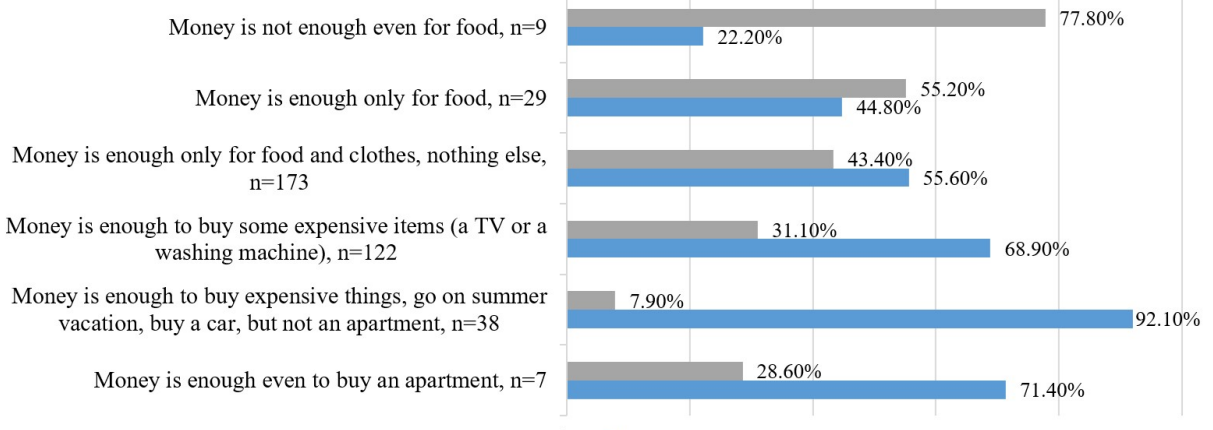

- Region $=$ Yerevan

Chart 4

The main expences of employees

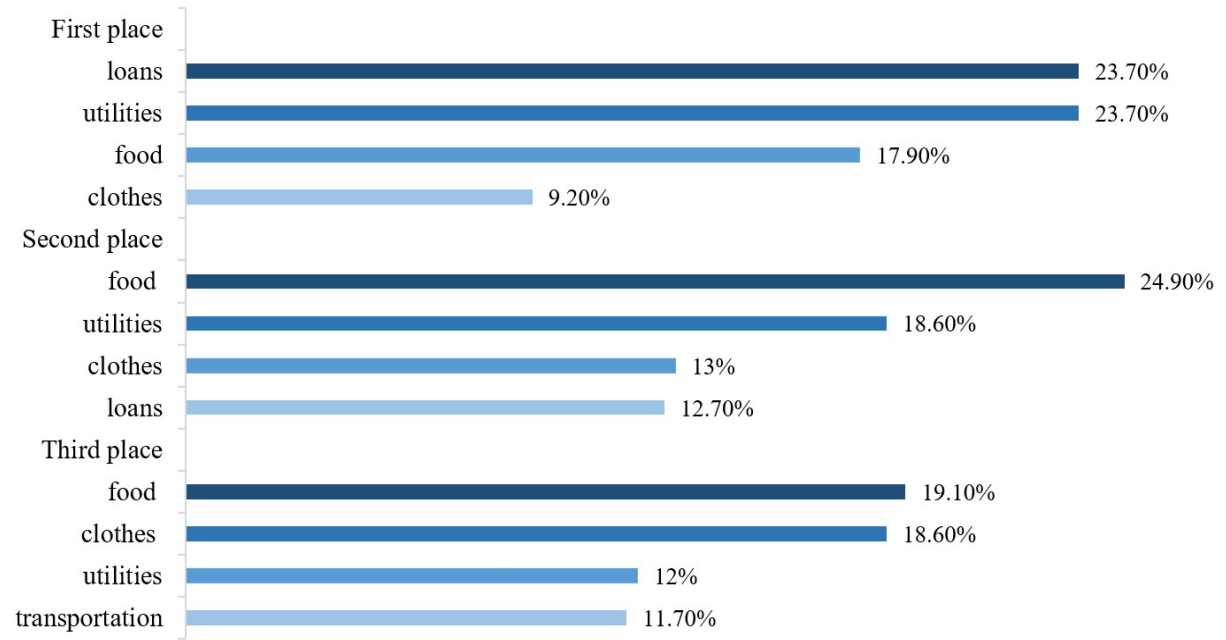

The indicators of precariousness: Now that we have presented the socioeconomic background of the workers, we will discuss the characteristics of precariousness. The first indicator is employment precariousness, which includes instability of employment responsibilities, regulations, contracts, and dismissal.

The research shows that the requirements for working in the field of food service and trade usually are not about qualifications but personal skills. Survey shows that to get a job, responders need professional practical skills (connected to the sector) in $38.9 \%$ of cases, past working experience in $26.8 \%$ of cases, 
education in $15.2 \%$ of cases, success/luck in $7.8 \%$ of cases, and help of relatives in $7.3 \%$ of cases $(\mathrm{n}=218)$. In addition, qualitative data also shows that workers usually need non-professional qualities such as appearance, attention, agility, sense of responsibility, patience, communication skills.

Concerning the instability of work, $66 \%$ of the respondents mentioned that they have an indefinite employment contract, $18.8 \%$ of participants do not have a (written) contract and $7.6 \%$ of them work under a fixed-term contract $(\mathrm{n}=$ 382). The results of the research show that the existence of a contract and/or the type of contract depends on the age of the employee (Chi-square test, P. Value $=0.250$, P. Sig. $=0.022$, Cramer's V=0.125, chart 5).

The contract type by the age groups $n=378$

Chart 5

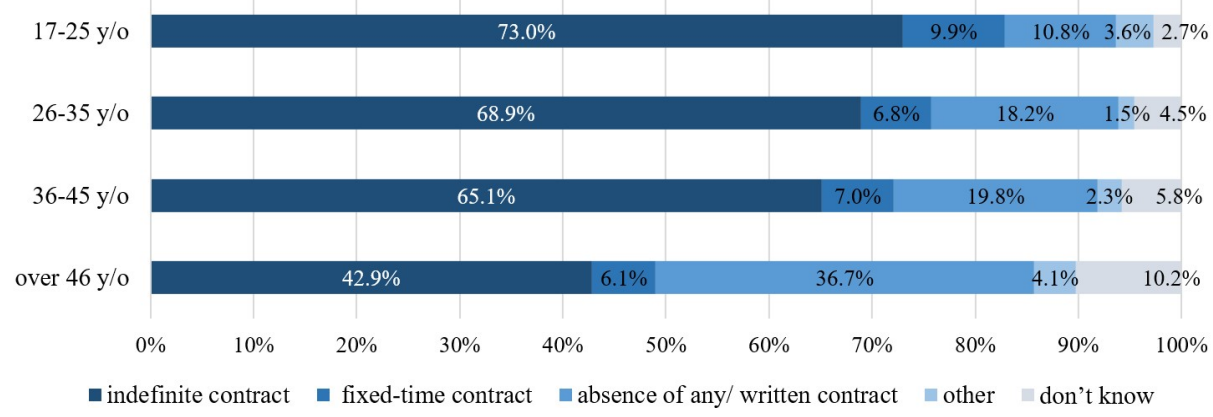

The results of the research show that about $20 \%$ of the respondents $(n=303)$ almost/completely don't read the terms of the contract, but $62.5 \%$ of the latter state that the working conditions fully correspond to the conditions presented in the contract. This shows that the clarification of responsibilities byword is typical, even if a written contract is signed.

Quantitative data also prove that uncontrolled factors play a decisive role in the organization of the work environment of employees in the sector of food service and catering. Working environment mostly depends on the needs of other people (clients) $(\mathrm{n}=381,77.3 \%)$, the work done by colleagues $(\mathrm{n}=380$, $63.7 \%)$, and only in $40.3 \%$ of cases direct management $(n=382)$. The $9.5 \%$ of respondents $(n=359)$ fully or partially agree with the statement that they can lose their job within six months and $10.3 \%$ are generally uncertain about the statement. $60.6 \%$ of the respondents think that in case of losing their job, it will not be difficult to find another job with the same salary.

Particularly, the work of the staff of public catering establishmens depends more on the work done by colleagues and on the direct control of management bodies (Chi-square test, P. Value $=-0.167, \mathrm{P}$. Sig. $=0.001$, Cramer's V $=$ $0.167)$.

According to $36.8 \%$ of the respondents, professional/practical skills are essential for career/promotion in the workplace, according to $27.5 \%$, work 
experience is essential, and according to $13.5 \%$, educational level is essential $(\mathrm{n}=235)$. These data also show that in $20 \%$ of cases, the promotion factors have no objective justification. In particular, the relations with the management staff prevail in them with $11 \%$ frequency.

The third indicator is the precariousness of income, which includes instability of income size, obtaining frequency, and minimum wage mechanisms. In the paragraph on workers' economic background, we already discussed some issues that introduce the precariousness of income, especially the sub-indicator of minimum wage mechanisms. Now we will present additional information on the criteria.

The $70.4 \%$ of respondents receive bonuses (honorariums) at work $(\mathrm{n}=$ 378). This criterion is statistically significant with (1) contract presence/absence; about received bonuses mentioned $74.6 \%$ of the respondents who signed a contract at work and $56.9 \%$ of those who did not have a contract $(\mathrm{n}=359$, Chi-square test, P. Value $=0.156$, P. Sig. $=0.003$, Cramer's V=0.156); and (2) the type of organization $(\mathrm{n}=260$, Chi-square test, P. Value $=0.570, \mathrm{P}$. Sig. $=0.000$, Cramer's V=0.329); $23.6 \%$ of employees in public catering establishments receive a bonus every day or almost every day, $29.8 \%$ receive once, or several times a week, $29.8 \%$ receive once or several times a month, when only $5.5 \%$ of supermarket employees receive a bonus once or several times a week, $22.7 \%$ once or several times a month, $22.7 \%$ once a quarter/season, and $45.5 \%$ once a year or rarely.

This difference directly depends on the principles of income generation in both workplaces. Qualitative data show that in catering establishments, especially barmen's and waiters' incomes and the frequency of acquisitions are less stable than those of supermarket employees, as the salaries of catering staff are formed by tips and the percentage of sales. However, due to that, the salaries of the employees in the food catering establishments are higher than the salaries of the employees in the supermarket; especially those who get more than 150000 AMD a month in $89.4 \%$ cases work at catering establishments, when $67.8 \%$ of supermarket workers get up to 100000 AMD monthly $(\mathrm{n}=382$, Chi-square test, P. Value $=0.244$, P. Sig. $=0.000$, Cramer's V $=0.244$ ).

The last indicator is the precariousness of working conditions which includes the instability of work nature (life-threatening work), schedule, opportunities to change it, breaks, vacations, accident/health insurance, and social benefits.

$62.8 \%$ of respondents think that work has no effect on their health, but for $29.4 \%$, it has a negative impact. The negative impact of work on health is mostly mentioned by the workers in the catering establishments $31.9 \%$, $\mathrm{n}=374$ ). The employees of the supermarket are less satisfied with their break opportunities than those in catering establishments $(\mathrm{n}=373$, Chi-square test, $\mathrm{P}$. Value $=0.251$, P. Sig. $=0.000$, Cramer's V $=0.251$, Chart 6) . 


\section{The Satisfaction With Break Opportunities By The Type Of Organisation N=373 \\ Chart 6}

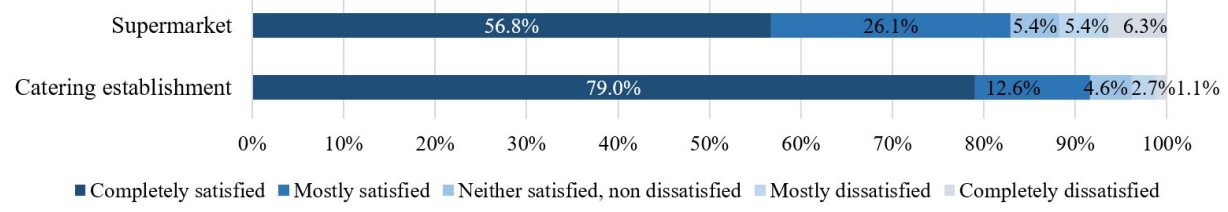

The research shows that employees stay at work later than 22:00 in 50.8\% of cases $(\mathrm{n}=382)$. The $21.2 \%$ of employees in the sector work more than 10 hours a day for more than 20 days a month. Such employees are significantly dominated in public catering establishments $(92.6 \%, \mathrm{n}=378$, Chi-square test, $\mathrm{P}$. Value $=0.343$, P. Sig. $=0.000$, Cramer's V $=0.343$ ).

However, $29.5 \%$ of the respondents do not have any day-offs during the year. Moreover, this criteria is significantly connected to the absence of written contracts; $48.5 \%$ of those who do not have a written contract do not have annual vocations $(\mathrm{n}=72$, Chi-square test, P. Value $=0.272$, P. Sig. $=0.000$, Cramer's $\mathrm{V}=0.272)$.

Finally, speaking about the instability of working schedule, $40.8 \%$ of the respondents mentioned that they could change their work schedule, $22.6 \%$ mentioned the work schedule was made by the organization, $20.0 \%$ mentioned that they could choose from given options and according to $16.6 \%$, they managed their work schedule $(n=380)$. At the same time, employees of public catering establishments are more likely to manage their schedule, in contrast to supermarket employees $(\mathrm{n}=380$, Chi-square test, P. Value $=0.184$, P. Sig. $=0.005$, Cramer's V $=0.184$ ).

Conclusion: The precariousness of the food service and trade sector is especially illustrated by the high level of instability of work responsibilities and regulations, which is due to the existence of intensive relationships with a large number of people, especially clients. The sector is also characterized by the incongruity of actual working conditions with contractual conditions, especially in public catering establishments.

The instability is also related to the income and the schedule mostly in the public catering establishments, where the salaries mostly (at least for waiters, barmen, sometimes managers) are formed by tips and percentage of sales. Here working hours are generally longer than in supermarkets, however, due to these two factors, the salaries of the employees in the catering establishments are higher than those of the employees in the supermarket.

This research allows emphasizing different social and economic issues of those involved in the sector. For example, most of them haven't got higher educations, a significant part of them are divorced, have economic difficulties, and can only buy food or clothes, some of them don't get even minimum wage state by legislation. In addition, because of the low professional and/or educational 
requirements, recruitment and growth prospectives of the sector are first formed on personal characteristics, such as appearance, relationships with management, acquaintances in the field, patience, diligence, then on professional characteristics; such as work experience, knowledge of the field, knowledge of the language. This leads to thoughts that the sector can be a good choice for low-class workers, for those who are not able to work in the profession because of different social and economic preconditions, which does not contradict but confirms the precarious nature of the field. During the research and especially conversations with respondents, we noticed the possibility of different risks and unfair distribution, which should definitely be considered in future studies.

\section{Bibliography}

1. Campbell I., Price R., (2016) "Precarious work and precarious workers: Towards an improved conceptualization", The Economic and Labour Relations Review

2. Gardawski J., Mrozowicki A., Trappmann V., Andrejczuk M., Burski J., Czarzasty J., Drabina-Różewicz A., Lorenzen J., Karolak M., Krasowska A., Neumann D., Seehaus A. (2020) "Young Precarious Workers in Poland and Germany. Insights into life strategies, political consciousness and activism"// Source: https://repozytorium.uni.wroc.pl/dlibra/publication/ 115847/edition/107171?language=en

3. Haydon D., Kumar N., (2020) "Industries Most and Least Impacted by COVID-19 from a Probability of Default Perspective - September Update" // Source: https:/www.spglobal.com/ marketintelligence/en/news-insights/blog/industries-most-andleast-impacted-by-covid19-from-a-probability-of-default-perspective-september-2020update

4. Jonsson, I., Nyberg, A. (2010) "Sweden: precarious work and precarious unemployment" // in Gender and the contours of precarious employment, ed Vosko Working paper

5. Labor Code of the Republic of Armenia, date of adoption: 09.11.2004, (in Armenian). Source: https://www.arlis.am/documentview.aspx?docid=66489

6. McGovern, P., Hill, S. and Mills, C. (2008) "Market, Class, and Employment", Oxford: Oxford University Press, ch. 3

7. McKay S., Jefferys S., Paraksevopoulou A., Kelesp J. (2012) "Study on Precarious work and social rights: Carried out for the European Commission", Working Lives Research Institute; Faculty of Social Sciences and Humanities; London Metropolitan University

8. Mikaelian, H. (2016) "Shadow economy in Armenia". Yerevan, Caucasus Institute

9. Mkrtchyan A., Osipyan A., Sahakyan S. (2020) "Social, economic and legal manifestations of Covid-19 pidemic in the Republic of Armenia", Konrad Adenauer Stiftung, Yerevan State University; Yerevan (in Armenian)

10. Rodgers J. Rodgers G. (1989) "Precarious Jobs in Labour Market Regulation: The Growth of Atypical Employment in Western Europe", International Institute for Labour Studies, Free University of Brussels

11. Standing G. (2011) "The Precariat: The New Dangerous Class", Bloomsbury Academic, New York

12. Vermishyan H., Michikyan S., Ghalamdaryan A., (2021) "Working conditions of employees in the field of food service and trade in Armenia", Armenian branch of the Friedrich Ebert Foundation (in Armenian)

13. Vosko L. (2010) "Managing the Margins: Gender, Citizenship, and the International Regulation of Precarious Employment”. Oxford: Oxford University Press

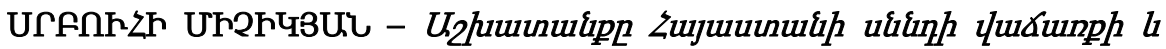

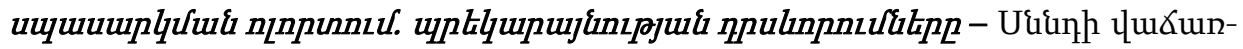

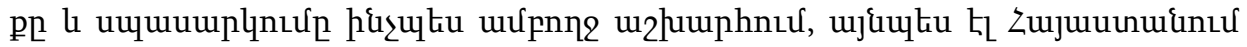

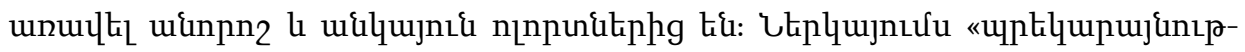

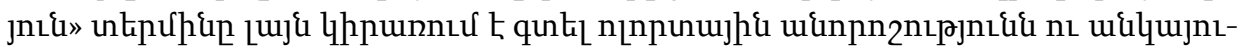




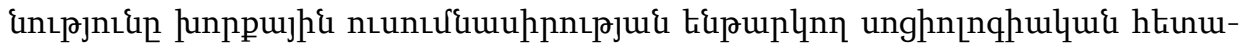

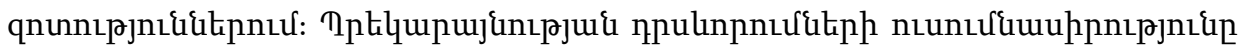

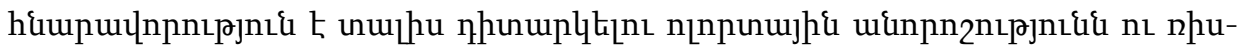

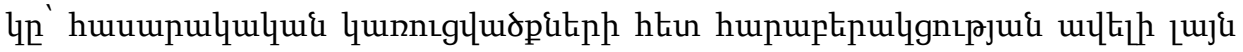

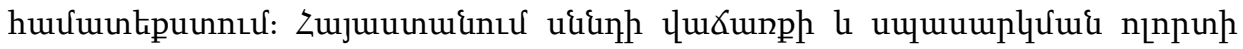

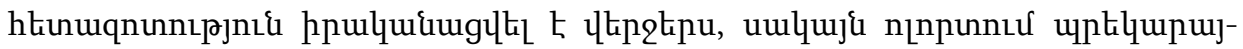

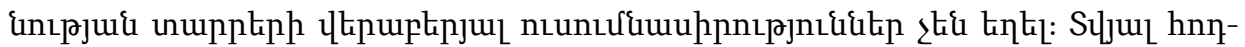

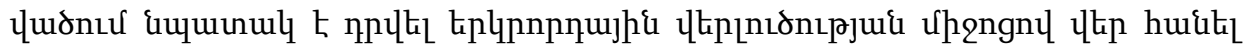

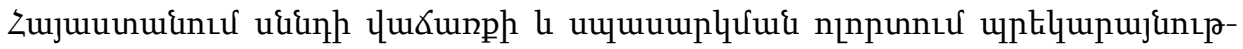

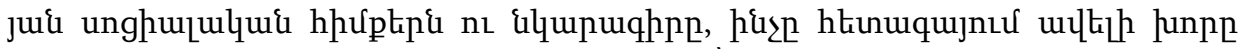

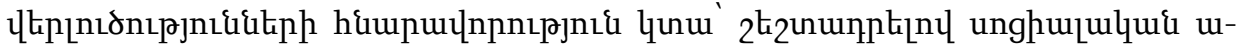

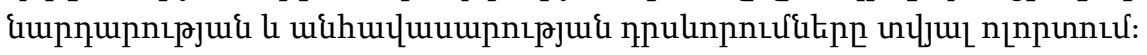

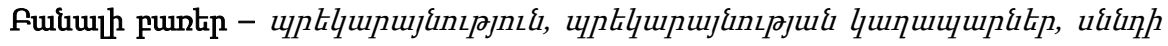

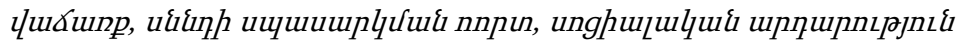

СРБУИ МИЧИКЯН - Работа в сфере общественного питания и торговли в Армении: паттерны прекарности. - Сектор продаж и обслуживания питания как во всем мире, так и в Армении считается наиболее нестабильным, с высокой долей риска. В настоящее время исследования нестабильности и рисков широко используют термин прекарность для описания ненадежности. Вместе с тем, исследований прекарности в сфере торговли и обслуживания питания не проводилось. Изучение паттернов прекарности позволяет глубже взглянуть на неопределенность и риски в контексте более широких социальных структур. Цель данной статьи - изучить паттерны прекарности, выраженные в данной области, посредством вторичного анализа результатов проведеного исследования в сфере услуг и торговли продуктами питания в Армении, что в дальнейшем позволит осуществить более глубинный анализ прекарности в контексте социальной несправедливости и неравенства.

Ключевые слова: прекарность, паттерны прекарности, торговля продуктами питания, общественное питание, сфера обслуживания, социальная справедливость 


\section{Abstract}

The food trade and service sector is considered to be the most uncertain, with a strong expression of instability both worldwide and in Armenia. Currently, the term precariousness is widely used in the field to describe the uncertainty and risks in the field. Research on food trade and services in Armenia has been conducted recently, but there have been no sociological studies on patterns of precariousness in the field. The study of patterns of precariousness provides an in-depth look at sectoral uncertainty and risk in relation to broader social structures. The purpose of this article is to study the patterns of precariousness expressed in the field through secondary analysis, which will provide opportunities for deeper analysis in the future, emphasizing the expressions of social injustice and inequality.

\section{Keywords}

precariousness, precarious patterns, food trade, food service sector

\section{Author}

Srbuhi Michikyan - SOCIES Expert Centre, Project Coordinator

\section{Email: srbuhi.michikyan@gmail.com}

\section{References}

Campbell I., Price R. (2016) "Precarious work and precarious workers: Towards an improved conceptualization", The Economic and Labour Relations Review. DOI: $10.1177 / 1035304616652074$

Gardawski J., Mrozowicki A., Trappmann V., Andrejczuk M., Burski J., Czarzasty J., Drabina-Różewicz A., Lorenzen J., Karolak M., Krasowska A., Neumann D., Seehaus A. (2020) "Young Precarious Workers in Poland and Germany. Insights into life strategies, political consciousness and activism" Source: 
https://repozytorium.uni.wroc.pl/dlibra/publication/115847/edition/107171?lang uage $=$ en

Haydon D., Kumar N. (2020) "Industries Most and Least Impacted by COVID-19 from a Probability of Default Perspective - September Update". Source: https://www.spglobal.com/marketintelligence/en/news-insights/blog/industriesmost-and-least-impacted-by-covid19-from-a-probability-of-default-perspectiveseptember-2020-update

Jonsson, I., Nyberg, A. (2010) "Sweden: precarious work and precarious unemployment". in Gender and the contours of precarious employment. Vosko Working paper.

Labor Code of the Republic of Armenia, date of adoption: 09.11.2004, (in Armenian). Source: https://www.arlis.am/documentview.aspx?docid=66489

McGovern, P., Hill, S. and Mills, C. (2008) "Market, Class, and Employment", Oxford: Oxford University Press, ch. 3. DOI: 10.1093/acprof:oso/9780199213375.001.0001

McKay S., Jefferys S., Paraksevopoulou A., Kelesp J. (2012) "Study on Precarious work and social rights: Carried out for the European Commission", Working Lives Research Institute; Faculty of Social Sciences and Humanities; London Metropolitan University

Mikaelian, H. (2016) "Shadow economy in Armenia". Yerevan, Caucasus Institute Mkrtchyan A., Osipyan A., Sahakyan S. (2020) "Social, economic and legal manifestations of Covid-19 pidemic in the Republic of Armenia", Konrad Adenauer Stiftung, Yerevan State University; Yerevan (in Armenian)

Rodgers J. Rodgers G. (1989) "Precarious Jobs in Labour Market Regulation: The Growth of Atypical Employment in Western Europe", International Institute for Labour Studies, Free University of Brussels

Standing G. (2011) "The Precariat: The New Dangerous Class", Bloomsbury Academic, New York. DOI: 10.5040/9781849664554 
Vermishyan H., Michikyan S., Ghalamdaryan A., (2021) "Working conditions of employees in the field of food service and trade in Armenia", Armenian branch of the Friedrich Ebert Foundation (in Armenian)

Vosko L, MacDonald M., Campbell I. (eds) (2009) "Gender and the Contours of Precarious Employment". London: Routledge. DOI: 10.4324/9780203874424

Vosko L. (2010) "Managing the Margins: Gender, Citizenship, and the International Regulation of Precarious Employment". Oxford: Oxford University Press 